\title{
Evaluation of serum concentrations of the selected cytokines in patients with localized scleroderma
}

\author{
Jolanta Budzyńska-Włodarczyk¹, Małgorzata M. Michalska-Jakubus², Małgorzata Kowal², Dorota Krasowska²
}

${ }^{1}$ Healthcare Center "Dermedica”, Zamosc, Poland

${ }^{2}$ Department of Dermatology, Venereology and Pediatric Dermatology, Medical University of Lublin, Lublin, Poland

Adv Dermatol Allergol 2016; XXXIII (1): 47-51

DOI: $10.5114 / p d i a .2015 .48044$

\begin{abstract}
Introduction: Localized scleroderma is an autoimmune disease primarily affecting the skin. The cause of disease remains unexplained although environmental factors are implicated, which are likely to be responsible for activation of the endothelium and subsequent inflammation leading to excessive synthesis of collagen and extracellular matrix components.

Aim: To determine concentrations of interleukin (IL)-27, transforming growth factor (TGF)- $\beta 1$, TGF- $\beta 2$, IL-6, and sIL-6R in patients with localized scleroderma compared to controls and to assess the relations between their levels and laboratory markers.

Material and methods: The study encompassed 17 females with localized scleroderma (aged 25-67). The control group consisted of 30 age-matched healthy women. The blood was sampled from the basilic vein. Serum levels of cytokines were determined using ELISA.

Results: The TGF- $\beta 2$ levels were found to be significantly lower in patients with localized scleroderma compared to controls. Concentrations of TGF- $\beta 1$ were decreased in scleroderma patients when compared to controls but without statistical significance. There were no significant differences in serum IL-6, sIL-6R and IL-27 levels between patients and the control group; however, we found a significant positive correlation between the level of sIL-6 and ESR among subjects with localized scleroderma.

Conclusions: The findings of decreased serum levels of TGF- $\beta 1$ and TGF- $\beta 2$ in patients with localized scleroderma demonstrate a possible association of these cytokines with pathogenesis of the disease. The results suggest also that sIL-6R is likely to be involved in inflammation in patients with localized scleroderma.
\end{abstract}

Key words: localized scleroderma, morphea, cytokines, inflammation fibrosis.

\section{Introduction}

Localized scleroderma (LS), also called morphea, belongs to the spectrum of autoimmune sclerotic diseases primarily affecting the skin. Depending on its clinical variant, the disease can also affect the subcutaneous tissue, fascia, muscles and bones. LS occurs in all races; predominantly in females $(2.6-6: 1)$. Its incidence rate is 0.4-2.7 individuals per 100 000. It can develop at any age, yet its peak incidence depends on the clinical variant; plaque morphea often occurs in adults aged 40-50 years whereas linear morphea in children aged 2-14 years [1-4].

Localized scleroderma is characterized by enhanced production of collagen and extracellular matrix (ECM) components, which are deposited in the skin and/or deeper tissues and are responsible for the clinical picture of the disease.

Numerous studies indicate familiar predisposition to the disease, the presence of microchimerism and frequent co-existence of autoimmune diseases, i.e. autoimmune thyroiditis, alopecia areata, vitiligo, diabetes mellitus type I, and ulcerative enteritis [5-7]. The environmental factors such as Borrelia burgdorferi, injuries, radiation and drugs ( $\beta$-blockers, bleomycin, D-penicillamine, bromocriptine) are also implicated in the etiopathogenesis of $\operatorname{LS}[2,8,9]$.

The interpenetrating genetic and environmental factors stimulate the immune system which generates the cellular and humoral response. Many cytokines and growth factors are involved in the pathogenesis of LS; in

Address for correspondence: Prof. Dorota Krasowska MD, PhD, Department of Dermatology, Venereology and Pediatric Dermatology, Medical University of Lublin, 13 Radziwiłłowska St, 20-080 Lublin, Poland, phone: +48 608098 578, fax: +48 815 323 647,

e-mail: dorota.krasowska@umlub.pl

Received: 28.02.2014, accepted: 17.07.2014. 
particular, transforming growth factor (TGF)- $\beta$, interleukin (IL)-4, IL-6, IL-10, IL-27, interferon (INF)- $\gamma$ and recently IL-17A have been found to be essential for the process of inflammation and fibrosis [10-14].

Transforming growth factor $\beta$ is a cytokine occurring in three isoforms (TGF- $\beta 1$, TGF- $\beta 2$, TGF- $\beta 3$ ). It shows multifaceted action and is involved in regulation of cell growth, differentiation and migration, synthesis and degradation of extracellular matrix components, processes of chemotaxis, apoptosis and in immune regulation [15-17]. Transforming growth factor $\beta$ is predominantly produced by mononuclear cells, i.e. activated lymphocytes and monocytes at the site of inflammatory reaction and by platelets. Transforming growth factor $\beta$ has been demonstrated to enhance the expression of collagen type I, III, VI and X, fibronectin and proteoglycans [18]. The increase in extracellular matrix components is stimulated by TGF- $\beta$ through inhibition of their degradation, inhibition of protease synthesis and activation of ECM protease inhibitors [19].

Interleukin 6 is considered the crucial factor regulating inflammatory and immune response. Interleukin 6 is produced by macrophages, monocytes, fibroblasts, endothelial cells, keratinocytes, $T$ and B lymphocytes, mast cells and chondrocytes [19]. The damaged skin can be the main source of IL-6. By stimulating the secretion of acute phase proteins, the cytokine is involved in regulation of local as well as general protective mechanisms limiting the injuries of the affected tissue $[19,20]$. Interleukin 6 stimulates proliferation of fibroblasts and production of collagen, leads to activation of B and T lymphocytes, increases synthesis of collagenase-inhibiting metalloproteinases. Thus it seems to be an extremely relevant factor in the pathogenesis of scleroderma [21-23].

Interleukin 6 receptor (IL-6R) of high affinity consists of two chains: an $80 \mathrm{kDa} \alpha$ chain capable of binding to a ligand, i.e. IL-6, yet unable to transmit the signal, and a $130 \mathrm{kD}$ a $\beta$ chain, which has a longer intracellular fragment and is capable of intracellular transmission of the signal [19]. The IL-6R $\alpha$ chain is expressed only on some cells, i.e. hepatocytes, neutrophils, monocytes, macrophages and some lymphocytes; gp130 expression, however, is observed in almost all body cells. The soluble IL-6 receptor is a product of proteolytic cleavage of $\alpha$ chain. It binds to IL- 6 enhancing its action, mediates signal transmission and is capable of impulse conduction after binding to $\beta$ chain present in the cell membrane [20].

Interleukin 27 (IL-27) belongs to a group of IL-6/IL-12 cytokines as its structure and function are similar. Interleukin 27 is released by activated macrophages and dendritic cells. It is produced by stimulated antigen-presenting cells, activates naive CD4+ T cells and stimulates the expression of INF- $\gamma$ independently of IL-12 [12, 13].

Noteworthy, IL-27 exerts double effects on the immune system - stimulatory by increased production of proinflammatory cytokines [24-26] and inhibitory by activating anti-inflammatory cytokines, i.e. IL-10 [27, 28].

\section{Aim}

The aim of the present study was to evaluate concentrations of the selected cytokines, i.e. IL-27, TGF- $\beta 1$, TGF- $\beta 2$, IL-6 and its soluble receptor (sIL-6R), in patients with LS compared to healthy individuals. Moreover, concentrations of cytokines in LS were assessed according to the markers of inflammation.

\section{Material and methods}

The study encompassed 17 female patients with confirmed histopathologically LS aged 25-67 years (mean age: $45.3 \pm 14.6$ years) hospitalized at the Department of Dermatology, Medical University of Lublin in 2005-2008. The control group consisted of 30 healthy females aged 24-63 years (mean age: $44.8 \pm 10.9$ years).

The clinical form, duration of the disease and its activity were assessed.

According to the clinical form and degree of tissue involvement patients were divided into the following groups: 1) patients with disseminated morphea, 2) patients with linear morphea, 3) patients with morphea profunda, 4) patients with plaque morphea.

The duration of disease was defined as the period from the onset of the first LS symptom to patient evaluation. The duration of disease ranged from 1 year to 45 years (mean: 10.7 years).

Based on the disease activity, two groups were distinguished - patients with an active and with inactive form, wherein the active form of LS was characterized by the presence of indurated plaques or linear lesions of whiteyellowish or porcelain white colour and with lilac ring.

All participants were informed about the objective of the study and gave their consent for inclusion. The study design was approved by the Bioethics Committee for Clinical Research connected with the Medical University (no. KE 0254/211/2006).

Peripheral blood was collected from all patients and healthy controls from the basilic vein in the volume of $8 \mathrm{ml}$. Blood was sampled in morning hours in the fasting state during routine diagnostic examinations and then was immediately centrifuged at 1000xg for $15 \mathrm{~min}$. The obtained serum was divided into $200 \mu$ volumes and cryopreserved at $-75^{\circ} \mathrm{C}$ to $-80^{\circ} \mathrm{C}$ until the entire material was collected and used for further determinations.

Serum concentrations of IL-27, TGF- $\beta 1$, TGF- $\beta 2$, IL- 6 , and SIL-6R were determined by using a commercial enzyme-linked immunosorbent assay (ELISA) kit (Quantikine Human Immunoassay, R\&D Systems, USA) and automated ELISA ELX800 reader (BioTek Instruments, USA).

\section{Statistical analysis}

The results were statistically analysed. The values of parameters measured on a nominal scale were characterized by a number and percentage whereas those on a quotient scale using a mean, standard deviation, me- 
dian, upper and lower quartile with the range of variability included.

Differences between groups were considered significant at the $5 \%$ level $(p<0.05)$. The results were presented in tables and figures. Statistical analyses were performed using Statistica v.10.0 software (StatSoft, Poland).

\section{Results}

Analysis of LS groups according to the clinical form of disease and disease activity are presented in Tables 1 and 2 , respectively.

In the study group, erythrocyte sedimentation rate (ESR) ranged from 3 to $35 \mathrm{~mm} / \mathrm{h}$ (mean: $12.3 \mathrm{~mm} / \mathrm{h}$ ). The level of C-reactive protein (CRP) in LS patients was within the range of $0.5-43.2 \mathrm{mg} / \mathrm{l}$ (mean: $5.08 \mathrm{mg} / \mathrm{l}$ ). Elevated levels of CRP were found in $2(11.8 \%)$ patients whereas in $15(88.2 \%)$ were within normal limits.

The results of IL-27, TGF- $\beta 1$, TGF- $\beta 1, I L-6$, and SIL-6R concentrations in the LS group $(N 1=17)$ and in the control group $(N 2=30)$ are presented in Table 3. Correlations between serum levels of cytokines and ESR or CRP are listed in Table 4.

We found decreased levels of TGF- $\beta 1$ in sera of LS patients when compared with healthy controls, however the differences did not reach statistical significance $(p=0.09)$. In contrast, concentrations of TGF- $\beta 2$ were significantly lower in the LS group compared to controls $(p=0.04)$.

The correlations of cytokine concentrations with ESR and CRP were analysed in the study group. A positive correlation only between SIL- 6 and ESR $(R=0.71$; $p=0.002$ ) was found. There were no significant correlations revealed between serum levels of other analysed cytokines, i.e. IL-6, IL-27, TGF- $\beta 1$, TGF- $\beta 2$ and ESR or CRP in the LS group ( $p>0.05)$. The results are listed in Table 4.

Correlations between examined cytokines and clinical form, duration and activity of the disease were not evaluated due to the small number of patients in particular groups.
Table 1. The study group according to the variant of localized scleroderma

\begin{tabular}{lcc}
\hline Clinical variant & $\begin{array}{c}\text { Number } \\
\text { of patients }\end{array}$ & $\begin{array}{c}\text { Percentage } \\
\text { of patients (\%) }\end{array}$ \\
\hline Disseminated morphea & 9 & 52.9 \\
\hline Linear morphea & 4 & 23.5 \\
\hline Morphea profunda & 2 & 11.8 \\
\hline Morphea en plaque & 2 & 11.8 \\
\hline Total & 17 & 100 \\
\hline
\end{tabular}

Table 2. The study group according to the activity of disease

\begin{tabular}{lcc}
\hline Activity & $\begin{array}{c}\text { Number } \\
\text { of patients }\end{array}$ & $\begin{array}{c}\text { Percentage } \\
\text { of patients (\%) }\end{array}$ \\
\hline Active & 15 & 88.2 \\
\hline Inactive & 2 & 11.8 \\
\hline Total & 17 & 100 \\
\hline
\end{tabular}

\section{Discussion}

Excessive synthesis of collagen and extracellular matrix components is crucial for skin fibrosis in LS. The cause of this phenomenon has not been fully elucidated yet profibrotic cytokines IL-4, IL-6, and TGF- $\beta$ seem to be strongly involved. Serum levels of IL-2, IL-4, IL-6, IL-8, and IL-13 as well as soluble factors CD23 and CD30 have been studied in patients with LS and a correlation between their levels and the clinical variant or activity of disease was demonstrated [29-31].

Interleukin-6 was demonstrated to increase the production of collagen and aminoglycans in the fibroblast culture and some authors disclosed increased levels of IL-6 in patients with LS as well as in those with systemic sclerosis and a correlation between the level of this cytokine and clinical improvement of skin lesions, which indicates a crucial role of IL- 6 in the metabolism of connective tissue [32-34]. Ihn et al. detected increased IL-6

Table 3. Concentrations of cytokines the LS group and controls

\begin{tabular}{|c|c|c|c|c|c|c|c|c|}
\hline Cytokines & Group & Mean & SD & Median & $\begin{array}{l}\text { Lower } \\
\text { quartile }\end{array}$ & $\begin{array}{l}\text { Upper } \\
\text { quartile }\end{array}$ & Range & $\begin{array}{c}\text { Statistical } \\
\text { analysis }\end{array}$ \\
\hline \multirow[t]{2}{*}{ IL-27 [pg/ml] } & Control & 21.8 & 45.9 & 8.9 & 6.8 & 11.5 & $0.1-209.7$ & \multirow{2}{*}{$\begin{array}{l}Z=1.00 \\
p=0.32\end{array}$} \\
\hline & Affected & 68.8 & 144.4 & 10.4 & 4.5 & 15.7 & $1.7-521.9$ & \\
\hline \multirow[t]{2}{*}{ TGF- $\beta 1[\mathrm{pg} / \mathrm{ml}]$} & Control & 42867.5 & 17141.0 & 43305.1 & 30617.2 & 49755.8 & 14019.3-82814.1 & \multirow{2}{*}{$\begin{array}{l}Z=-1.70 \\
p=0.09\end{array}$} \\
\hline & Affected & 34265.3 & 11904.2 & 33926.8 & 30212.1 & 40595.6 & 7119.7-61664.7 & \\
\hline \multirow[t]{2}{*}{ TGF- $\beta 2$ [pg/ml] } & Control & 309.8 & 96.9 & 294.7 & 225.6 & 340.9 & $185.9-557.1$ & \multirow{2}{*}{$\begin{array}{c}Z=-2.06 \\
p=0.04\end{array}$} \\
\hline & Affected & 258.4 & 90.4 & 229.1 & 197.6 & 256.8 & $170.3-520.1$ & \\
\hline \multirow[t]{2}{*}{ IL-6 [pg/ml] } & Control & 44.7 & 11.0 & 41.7 & 37.9 & 46.6 & $32.9-87.8$ & \multirow{2}{*}{$\begin{array}{l}Z=1.39 \\
p=0.16\end{array}$} \\
\hline & Affected & 54.1 & 25.3 & 49.1 & 38.2 & 60.6 & $32.4-139.3$ & \\
\hline \multirow[t]{2}{*}{ sIL-6R [pg/ml] } & Control & 516.4 & 213.6 & 484.1 & 357.8 & 622.9 & $242.6-1220.5$ & \multirow{2}{*}{$\begin{array}{c}Z=-0.66 \\
p=0.51\end{array}$} \\
\hline & Affected & 464.1 & 145.7 & 470.1 & 340.2 & 539.8 & 225.0-782.1 & \\
\hline
\end{tabular}


Table 4. Correlation between concentrations of cytokines and ESR as well as CRP in patients with localized scleroderma

\begin{tabular}{lcc}
\hline Parameters & $\begin{array}{c}\text { Test } \\
\text { function } \\
\text { value } R\end{array}$ & $\begin{array}{c}\text { Level of } \\
\text { significance } \\
p\end{array}$ \\
\hline IL-27 [pg/ml] and OB $[\mathrm{mm} / \mathrm{h}]$ & -0.25 & 0.33 \\
\hline IL-27 $[\mathrm{pg} / \mathrm{ml}]$ and CRP $[\mathrm{mg} / \mathrm{l}]$ & -0.11 & 0.67 \\
\hline TGF- $\beta 1[\mathrm{pg} / \mathrm{ml}]$ and OB $[\mathrm{mm} / \mathrm{h}]$ & -0.10 & 0.71 \\
\hline TGF- $\beta 1[\mathrm{pg} / \mathrm{ml}]$ and CRP $[\mathrm{mg} / \mathrm{l}]$ & -0.23 & 0.37 \\
\hline TGF- $\beta 2[\mathrm{pg} / \mathrm{ml}]$ and OB $[\mathrm{mm} / \mathrm{h}]$ & -0.04 & 0.86 \\
\hline TGF- $\beta 2[\mathrm{pg} / \mathrm{ml}]$ and CRP $[\mathrm{mg} / \mathrm{l}]$ & -0.18 & 0.50 \\
\hline IL-6 $[\mathrm{pg} / \mathrm{ml}]$ and OB $[\mathrm{mm} / \mathrm{h}]$ & 0.43 & 0.09 \\
\hline IL-6 $[\mathrm{pg} / \mathrm{ml}]$ and CRP $[\mathrm{mg} / \mathrm{l}]$ & 0.44 & 0.08 \\
\hline sIL-6R $[\mathrm{pg} / \mathrm{ml}]$ and OB $[\mathrm{mm} / \mathrm{h}]$ & 0.71 & 0.002 \\
\hline sIL-6R $[\mathrm{pg} / \mathrm{ml}]$ and CRP $[\mathrm{mg} / \mathrm{l}]$ & 0.45 & 0.07 \\
\hline
\end{tabular}

in serum of 23/48 patients with LS [35]. Moreover, the authors observed significant differences in IL-6 levels in patients with LS and those with systemic sclerosis. Interestingly, increased IL- 6 was detectable in serum of 12/16 patients suffering from generalized morphea and in 9/22 patients with linear morphea. The authors also found a positive correlation between serum levels of IL-6 and the presence of anti-histone antibodies [34].

In the other study, a significant increase in IL-6 mRNA was revealed in the affected skin of patients with LS compared to healthy volunteers. Interestingly, with the improvement of skin lesions following radiation with a UVA1, the IL- 6 level in the affected skin and its serum concentration substantially decreased [32].

However, in our study, no significant differences were observed between serum IL-6 and sIL-6R levels in patients with LS compared to controls. Interestingly, we found a significant positive correlation between the leve of sIL-6R and ESR.

Different results were reported by Nagaoka et al., who found significantly elevated levels of sIL-6R in patients with LS compared to controls and patients with systemic sclerosis [34]. Elevated levels of sIL-6R in the group with $\mathrm{LS}$ were correlated with the presence of IgM anti-histone antibodies, rheumatoid factor and extent of skin lesions. The authors also observed an increased serum concentration of IL-6R $\beta$ chain in the study group which were positively correlated with the levels of IgG anti-histone antibodies [34]. The findings reflect the activation of IL-6/ sIL-6R system, which can contribute to the development of sclerotic lesions in patients with LS.

Furthermore, our findings did not reveal significant differences in concentrations of IL-27 between patients with LS and controls. It is difficult to compare these results with other findings since similar studies are lacking.
Our results demonstrate significantly reduced serum TGF- $\beta 2$ levels in patients with LS compared to controls. Moreover, decreased concentrations of TGF- $\beta 1$ were observed in patients with LS when compared to healthy individuals although without statistical significance. These results are in contrast to a study of Restrepo et al., who did not observe significant differences in both TGF- $\beta 1$ and TGF- $\beta 2$ expression in the affected skin of patients with linear scleroderma compared to healthy individuals [36]. In addition, the recent study of Dańczak-Pazdrowska et al. also did not detect differences in either plasma levels of TGF- $\beta 1$ or TGF- $\beta 1$ expression in peripheral blood mononuclear cells and skin between patients with plaque morphea and healthy controls, regardless of disease activity and its duration [37]. Moreover, according to Uziel et al., children with LS had significantly elevated serum levels of TGF- $\beta 1$ compared to controls [38]. The highest levels were observed in patients with linear scleroderma of limbs and generalized variant of LS. The multiple regression analysis did not show significant relations between serum TGF- $\beta 1$ levels and demographic factors (age, duration of disease) as well as laboratory results (ESR, eosinophil count, levels of IgG and ANA antibodies). Moreover, there was no significant correlation between TGF- $\beta 1$ levels versus activity and clinical variant of disease [38]. It is difficult to compare these findings with ours since the structures of examined groups of patients varied significantly. Our study was conducted in adult patients whereas Uziel et al. studied paediatric population. The rationale for reported differences may be that TGF- $\beta 1$ and TGF- $\beta 2$ are likely to accumulate in inflammatory infiltrations near blood vessels in patients with LS, which can substantially reduce their serum levels in the affected.

Interesting findings were reported by Querfeld et al. who studied TGF- $\beta 1 \mathrm{~m}$ RNA expression using in situ hybridization and immunohistochemical methods with anti-TGF- $\beta 1$ antibodies in the skin of patients with LS and systemic sclerosis [39]. The authors detected TGF- $\beta 1$ expression near the blood vessels only in the skin of patients with inflammatory infiltrations. The TGF- $\beta 1$ expression was not found in controls and in patients with sclerosis. Similar results were obtained for TGF- $\beta 2$ mRNA expression [39].

\section{Conclusions}

The results suggest that the soluble receptor of IL- 6 (IL-6R) is likely to be involved in the stimulation of inflammation in patients with LS. 2 . The findings regarding serum levels of TGF- $\beta 1$ and TGF- $\beta 2$ in patients with LS demonstrate a possible involvement of this cytokine in the pathogenesis of LS.

\section{Conflict of interest}

The authors declare no conflict of interest. 


\section{References}

1. Silman A, Jannini S, Symmons D, Bacon P. An epidemiological study of scleroderma in the West Midlands. Br J Rheumatol 1988; 27: 286-90.

2. Kreuter A. Localized scleroderma. Dermatol Ther 2012; 25: 135-147.

3. Murray KJ, Laxer RM. Scleroderma in children and adolescents. Rheum Dis Clin North Am 2002; 28: 603-24.

4. Peterson LS, Nelson AM, Su WP, et al. The epidemiology of morphea (localized scleroderma) in Olmsted County 19601993. J Rheumatol 1997; 24: 73-80.

5. Fett NM. Morphea: evidence-based recommendations for treatment. Indian I Dermatol Venereol Leprol 2012; 78: 135-41.

6. Leitenberger JJ, Cayce RL, Haley RW, et al. Distinct autoimmune syndromes in morphea: a review of 245 adult and pediatric cases. Arch Dermatol 2009; 145: 545-50.

7. Zulian F, Athreya BH, Laxer R, et al. Juvenile localized scleroderma: clinical and epidemiological features in 750 children. An international study. Rheumatology (Oxford) 2006; 45: 614-20.

8. Alonso-Llamazares J, Persing DH, Anda P, et al. No evidence for Borrelia burgdorferi infection on lesions of morphea and lichen sclerosus et atrophicus in Spain. A prospective study and literature review. Acta Derm Venereol 1997; 77: 299-304.

9. Weide B, Schittek B, Klyscz T, et al. Morphoea is neither associated with features of Borrelia burgdorferi infection, nor is this agent detectable in lesional skin by polymerase chain reaction. Br J Dermatol 2000; 143: 780-5.

10. Gu YS, Kong J, Cheema GS, et al. The immunobiology of systemic sclerosis. Semin Arthritis Rheum 2008; 38: 132-60.

11. Schoenherr C, Weiskirchen R, Haan S. Interleukin-27 acts on hepatic stellate cells and induces signal transducer and activator of transcription 1-dependent responses. Cell Commun Signal 2010; 19: 8-19.

12. Shimozato O, Sato A, Kawamura K, et al. The secreted form of p28 subunit of interleukin (IL)-27 inhibits biological function of IL-27 and suppresses anti-allogenic immune responses. Immunology 2009; 128: e818-25.

13. Dańczak-Pazdrowska A, Kowalczyk M, Szramka-Pawlak B, et al. Interleukin-17A and interleukin-23 in morphea. Arch Med Sci 2012; 8: 1089-95.

14. Shabgah AG, Fattahi E, Shahneh FZ. Interleukin-17 in human inflammatory diseases. Adv Dermatol Allergol 2014; 31: 256-61.

15. Gorelik L, Flavell RA. Transforming growth factor-beta in T-cell biology. Nat Rev Immunol 2002; 2: 46-53.

16. Letterio JJ, Roberts $A B$. Regulation of immune responses by TGF-beta. Ann Rev Immunol 1998; 16: 137-61.

17. Stępień-Wyrobiec O, Hrycek A, Wyrobiec G. Transforming growth factor beta (TGF-beta): its structure, function, and role in the pathogenesis of systemic lupus erythematosus. Post Hig Med Dosw 2008; 62: 688-93.

18. Inn H. The role of TGF-beta signaling in the pathogenesis of fibrosis in scleroderma. Arch Immunol Ther Exper (Warsz.) 2002; 50: 325-31.

19. Kishimoto T, Akira S, Narazaki M, Taga T. Interleukin-6 family of cytokines and gp130. Blood 1995; 86: 1243-54.

20. Gołąb J, Jakóbsiak M, Zagożdżon R, Obląkowski P. Cytokiny. In: Immunologia. Gołąb J, Jakóbsiak M, Lasek W (eds), PWN, Warsaw 2002; 198-248.

21. Akasu R, From L, Kahn HJ. Lymphocyte and macrophage subsets in active and inactive lesions of lichen planus. Am J Dermatopathol 1993; 15: 217-23.
22. Lis-Swięty A, Brzezińska-Wcisło L, Rogala-Poborska I, Syguła E. Badanie stężenia rozpuszczalnego receptora interleukiny- 6 w surowicy chorych na twardzinę układową przed leczeniem i po leczeniu immunosupresyjnym. Adv Dermatol Allergol 2006; 23: 67-72.

23. Sepadin AN, Esser AC, Flejschmajer R. Immunopathogenesis of scleroderma - evolving concepts. Mt Sinai J Med 2001; 68: 233-42.

24. Hamano S, Himeno K, Miyazaki Y, et al. WSX-1 is required for resistance to Trypanosomacruzi infection by regulation of proinflammatory cytokine production. Immunity 2003; 19: 657-67.

25. Pflanz S, Timans JC, Cheung J, et al. IL-27, a heterodimeric cytokine composed of EBI3 and p28 protein, induces proliferation of naive CD4+ T cells. Immunity 2002; 16: 779-90.

26. Villarino A, Hibbert L, Lieberman L, et al. The IL-27R (WSX-1) is required to suppress T cell hyperactivity during infection. Immunity 2003; 19: 645-55.

27. Awasthi A, Carrier Y, Peron JPS, et al. A dominant function for interleukin 27 in generating interleukin 10-producing anti-inflammatory T cells. Nat Immunol 2007; 8: 1380-9.

28. Yoshimura T, Takeda A, Hamano S, et al. Two-side roles of IL-27: induction of Th1 differentiation on naive CD4+ T cells versus suppression of proinflamatory cytokine production including IL-23-induced IL-17 on activated CD4+ T cells partially through STAT3 - dependent mechanism. J Immunol 2006; 177: 5377-85.

29. Hasegawa M, Sato S, Nagaoka T, et al. Serum levels of tumor necrosis factor and interleukin-13 are elevated in patients with localized scleroderma. Dermatology 2003; 207: 141-7.

30. Ihn H, Yazawa N, Kubo M, et al. Circulating levels of soluble CD30 are increased in patients with localized scleroderma and correlated with serological and clinical features of the disease. J Rheumatol 2000; 27: 698-702.

31. Takehara K, Sato S. Localized scleroderma is an autoimmune disorder. Rheumatology 2005; 44: 274-9.

32. Kreuter A, Hyun J, Skrygan M, et al. Ultraviolet A1-induced downregulation of human beta-defensins and interleukin-6 and interleukin-8 correlates with clinical improvement in localized scleroderma. Br J Dermatol 2006; 155: 600-7.

33. Hasegawa M, Sato S, Takehara K. Augmented production of transforming growth factor-beta by cultured peripheral blood mononuclear cells from patients with systemic sclerosis. Arch Dermatol Res 2004; 296: 89-93.

34. Nagaoka T, Sato S, Hasegawa M, et al. Serum levels of soluble interleukin-6 receptor and soluble gp130 are elevated in patients with localized scleroderma. J Rheumatol 2000; 27: 1917-21.

35. Ihn H, Sato S, Fujimoto M, et al. Demonstration of interleukin-2, interleukin-4 and interleukin-6 in sera from patients with localized scleroderma. Arch Dermatol Res 1995; 287: 193-7.

36. Restrepo JF, Guzman R, Rodriguez G, Iglesias A. Expression of transforming growth factor-beta and platelet derived growth factor in linear scleroderma. Biomedica 2003; 4: 408-15.

37. Dańczak-Pazdrowska A, Kowalczyk MJ, Szramka-Pawlak B, et al. Transforming growth factor-beta1 in plaque morphea. Adv Dermatol Allergol 2013; 30: 337-42.

38. Uziel J, Feldman BM, Krafchik BR, et al. Increased serum levels of TGF-beta1 in children with localized scleroderma. Pediatr Rheumatol Online J 2007; 5: 22.

39. Querfeld C, Eckes B, Huerkamp C, et al. Expression of TGFbeta1, -beta2 and -beta3 in localized and systemic scleroderma. J Dermatol Sci 1999; 21: 13-22. 